\title{
ANALYSIS OF ELEMENTARY SCHOOL TEACHER EDUCATION STUDENTS' CREATIVITY IN CHANGING SONGS INTO SIGN LANGUAGES
}

\author{
Sri Hardiningsih ${ }^{1}$, Muh. Rijulul Akbar ${ }^{2}$, Sholihin $^{3}$ \\ ${ }^{1,2,3}$ Elementary Education Study Program, STKIP Taman Siswa Bima, Indonesia
}

\begin{tabular}{|c|c|}
\hline Article Info & ABSTRACT \\
\hline $\begin{array}{l}\text { Article history: } \\
\text { Received: } 03-02-2021 \\
\text { Revised: } 14-03-2021 \\
\text { Published: } 10-05-2021\end{array}$ & $\begin{array}{l}\text { Education for Children with Special Needs (PABK) is an optional course in the El- } \\
\text { ementary School Teacher Education Students (PGSD) study program where in this } \\
\text { course, there is a hearing difficulty (deaf). One of the strategies that prospective ed- } \\
\text { ucators (in this case students) can do is to prepare themselves when later adapting to } \\
\text { children who have hearing impairments. The strategy that can be done in dealing with }\end{array}$ \\
\hline $\begin{array}{l}\text { Keywords: } \\
\text { Elementary School } \\
\text { Students } \\
\text { Creativity } \\
\text { Sign Language }\end{array}$ & $\begin{array}{l}\text { So that the need for students to be trained at least to be able to use simple sign lan- } \\
\text { guage. So, students are directed to be able to compose songs into sign language. The } \\
\text { type of this research is a quantitative descriptive study which aims to determine the } \\
\text { creativity of students in composing songs into sign language as one of the strategies } \\
\text { in dealing with children with special needs hearing impairments. The subjects in this } \\
\text { study were students who were selected based on purposive sampling with the criteria } \\
\text { desired by the researcher. This research was conducted by filling in the instruments } \\
\text { that had been validated by the expert judgement. The results showed that in general, } \\
\text { students were able to compose songs into sign language. Based on these results, it can } \\
\text { be concluded: that the test results assessed from the research instrument, students were } \\
\text { able to compose songs into sign language quite well, this is shown in the results where } \\
77 \% \text { with a score of } 59-69 \text { with a total of } 11 \text { students were able to compose songs into } \\
\text { sign language. Meanwhile, } 23 \% \text { with a score of } 70-80 \text { with a total of } 4 \text { students were } \\
\text { able to compose songs into sign language well. }\end{array}$ \\
\hline
\end{tabular}

This is an open access article under the CC BY-SA license.

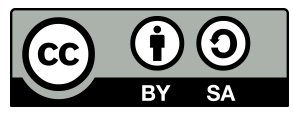

\section{Corresponding Author:}

Sri Hardiningsih,

Elementary Education Study Program, STKIP Taman Siswa Bima,

J1. Pendidikan Taman Siswa, Belo, Palibelo, Bima, Nusa Tenggara Barat, Indonesia

Email: sryhardiningsih@gmail.com

\section{INTRODUCTION}

One of the elective courses in the Primary School Teacher Education study program at STKIP Taman Siswa Bima is Education for Children with Special Needs (PABK). This course is a course that students take as a provision which will later be applied to schools that have students with special needs or are also called inclusive schools where students who have special needs or obstacles can study together with other students. In addition, so far, the learning process of PABK courses has been more about theory for children with special needs, less about the strategies or methods that educators will do when dealing with students who have special obstacles or needs. Whereas PABK, is not only theoretical, but also should be analytical in which educators are also required to have the ability to be creative in solving problems related to both media and methods. So 
that educators are required to be able to apply different methods, so that later they can attract the students' attention, especially those who experience special needs or obstacles in terms of hearing difficulties (deaf). Especially in today's education, students who experience special needs can study together with children who have no special barriers or needs. It is said to have special needs if students have abnormalities both physically and mentally or have the potential for special intelligence and talents (Nurmawanti, Haryati, Radiusman, Anar, \& Novitasari, 2020; Rahmatih, Wardani, Warthini, Astria, \& Fauzi, 2020; Sutisna, Indraswati, Nursaptini, Novitasari, \& Sobri, 2020; Widodo, Haryati, Maulyda, Umar, \& Erfan, 2020). This kind of education is known as inclusive education. Inclusive education is still considered an approach that only serves children with/with physical and mental disabilities and places them in special schools (Haryati, Radiusman, Nurmawanti, Anar, \& Widodo, 2020; Radiusman, Nurmawanti, Novitasari, Haryati, \& Simanjuntak, 2020; Wardani, Warthini, Rahmatih, Astria, \& Nurwahidah, 2020; Warthini, Wardani, Rahmatih, Nurwahidah, \& Astria, 2020). This is in line with $31^{s t}$ article of the UUD 1945 which states that all citizens have the right to education and the regulation of the Governor of West Nusa Tenggara No.2 of 2016 concerning the implementation of inclusive education.

In addition, of course, the learning process in each basic education unit must be interactive, inspirational, fun, challenging (Layyinah, 2017). Moreover, it should motivate students to be active; provide sufficient scope for students' creativity and independence according to their talents, interests, and physical development, as well as their psychological. According to Kemp in Sanjaya (2006), learning strategy is a learning activity that must be done by teachers and students.

Based on the above, the teacher must make every effort to bring quality education to schools, but this is not as easy as imagined. Especially in learning by involving children with special needs, for normal students or those without obstacles, sometimes they experience difficulties and are bored with the learning process and are less attracted. Therefore, based on the indication of the causes of learning difficulties that occur in students, teachers need to use appropriate strategies to overcome these problems. Djamarah and Zain (2002) suggest that a strategy is understood as an outline of action to achieve predetermined goals. The strategies for overcoming learning difficulties in students referred to above are efforts to achieve the desired learning goals.

In addition, based on the results of observations while teaching the PABK course, students have not been able to find solutions to solve problems that exist in children who experience hearing impairments (deaf). So that the effort or strategy taken is to direct students as prospective educators to have creative abilities in dealing with students who experience hearing problems during the learning process in elementary school later. So it is deemed necessary to prepare prospective educators to have strategies to overcome hearing barriers for children with special needs in creative ways. The approach to students who experience hearing impairments is carried out in a creative way with methods that are considered different in the learning process is one way to attract students' interest or attention in the learning process later.

Based on the problems above, it is deemed necessary to conduct research on the creativity of classroom teachers or prospective educators in overcoming hearing barriers for children with special needs in inclusive schools. Therefore, one of the strategies that can be carried out by prospective educators, in this case students of the PGSD study program at STKIP Taman Siswa Bima, is the creativity of college students in composing songs into sign language. This research is expected to describe the creativity of college students in overcoming hearing barriers for children with special needs. In addition, because it is seen from the lack of ability of students as prospective educators in elementary schools which does not rule out the possibility of having students with special needs for this phenomenon, it is necessary to take advantage of the potential for more creativity in students, especially in the realm of education (higher education) today. so, the object of study that will be carried out later can help solve a social phenomenon and develop student academic competence.

\section{RESEARCH METHOD}

This research uses descriptive quantitative method. The researcher tries to describe the data according to the characteristics of the variables, inventory, calculate, and present them (Sugiyono, 2014). Therefore, quantitative descriptive can provide an overview of the data systematically and carefully.

The data collection techniques used in the study were recorded using instruments that had been validated by a team of experts ( 2 people). The data collection instrument will help researchers to record student creativity in composing songs in sign language. The songs composed by students are not only national songs but students are given the freedom to compose songs according to their wishes. This is expected so that students 
can freely develop their creativity. After the song is composed, students are required to use social media to see how far other social media users respond. This will later be seen to what extent the response given to the video that has been uploaded by the student. And of course, it will describe the findings so that the accuracy of the research results is produced according to the predetermined formula.

The research questions contained in the instrument have been validated by an expert judgment. The questions on the validated research instrument are viewed from the aspect of creativity, namely; fluency, detail, originality, flexibility, and sensitivity. For more details, here is the form of the instrument and its validation.

Table 1. Assessment Guidelines

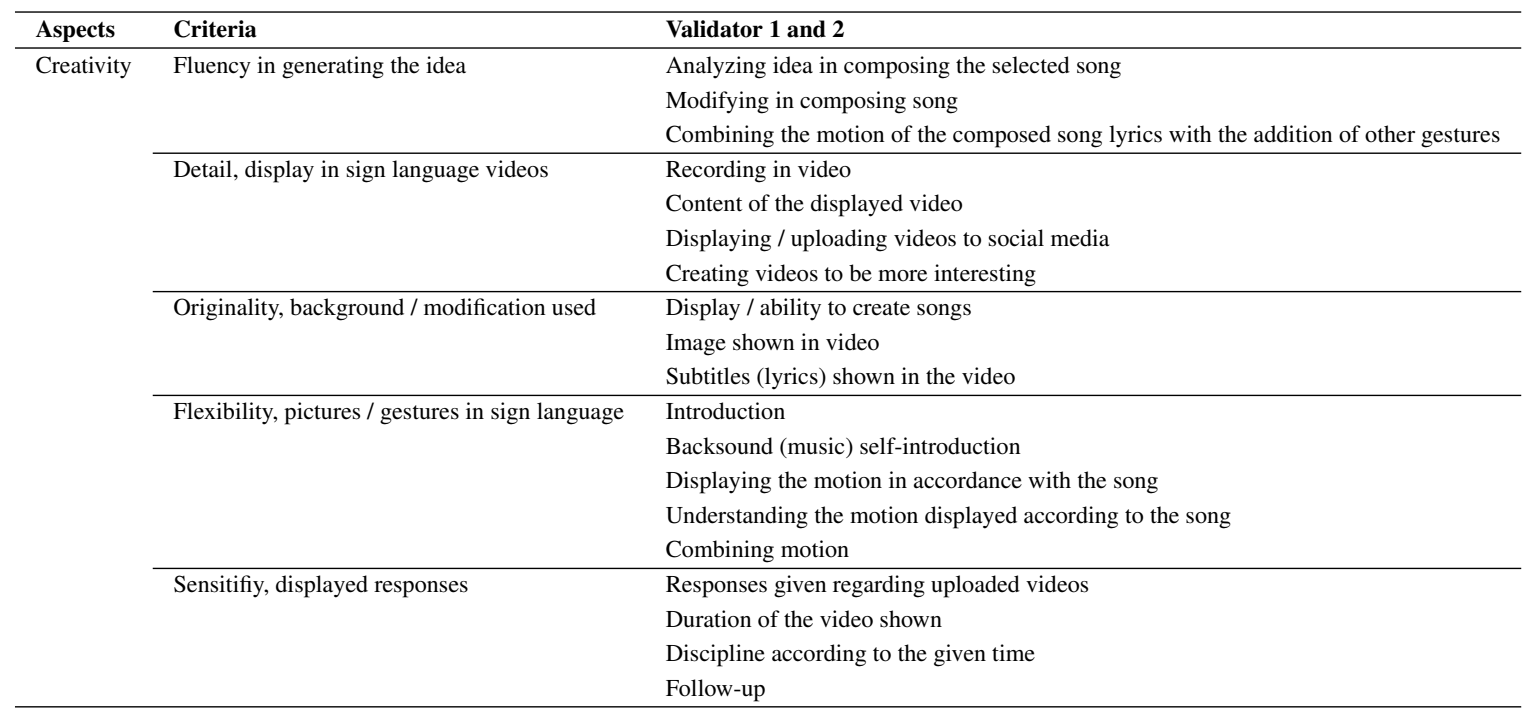

In addition, this study uses research instruments to measure the extent to which students' ability to create songs into sign language. Furthermore, the data collection techniques in this study were carried out through the following steps. First, identifying data on students' creativity abilities. Second, providing materials and assignments about composing songs into sign language. Third, students are asked to record into video and then upload it to social media. Fourth, tabulating data on student creativity in the instruments provided. Fifth, analyze the results of data collection and describe accurately according to calculations and percentages in charts or tables. Sixth, making conclusions and suggestions based on research results.

\section{RESULT AND DISCUSSION}

There are representative 15 students as subject of the evaluation stage. Based on the results of a questionnaire, the results of the analysis of students' creativity in composing songs into sign language were obtained that 11 students showed their creative abilities in composing songs into sign language were good enough. Meanwhile 4 students showed their creative abilities in writing songs into sign language can be said to be good. The following are the results of students' creativity data in composing songs into sign language, can be seen in Figure 1. Students' Creativity Results in composing songs into sign language. Furthermore, this research is described through tests with research instruments to measure the extent to which students' ability to compose songs in sign language. The test results are obtained with an indicator of creativity in the song that is modified. In addition, the results of this test are also obtained from existing data processing on creativity abilities in the form of journals, observations, and interviews.

The results of this study include test results with the application of student creativity research action in composing songs into sign language. Based on the results of the assessment of creativity in composing songs into sign language that have been done, it is known that the results of the ability of students in the PGSD STKIP Taman Siswa study program for semester V students are overall in the sufficient category. The lowest score is 59. Students who get this score are 4 students. And some others scored vulnerable 61-71. The complete results of the research on writing drama texts by students can be seen in the next table.

Based on the Figure 1, it can be concluded that most of the students are creative enough when com- 


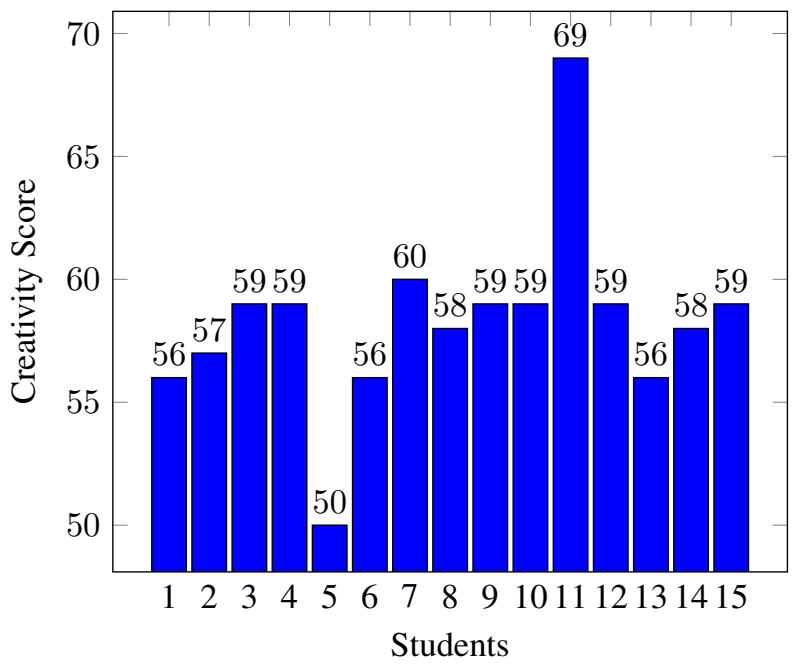

Figure 1. Creativity Test Results of Composing Songs into Sign Language

posing songs into sign language. With this value, it shows that completeness is achieved with an average value of 61.2. Based on the figure above, it is known that the weight of the creativity value of the students' ability in composing songs into sign language in this study is broadly in a fairly good range. So it can be concluded that this research is said to provide sufficient results as desired even though it does not show significant results on the creativity of the overall ability of students in composing songs into sign language. This is because students who get high scores are able to create songs into sign language according to the creativity indicators, where the aspects described are in accordance with the creativity indicators, song lyrics and gesture are appropriate, the images on the video display are quite clear, and good and directed.

Meanwhile students who get low scores are mainly due to students being less focused on what they are doing, in some parts of the video there are foreign voices recorded. Therefore, the results of creativity in composing songs into sign language do not meet the expected creativity indicators. In addition, these students still have difficulty adjusting between songs and sign language movements. Students lack in displaying settings / background, so that the appearance that appears becomes less attractive. The results of creativity in composing songs into sign language that are displayed by students can be seen in the presence of Figure 1 (bar chart), which shows that the category is quite good, namely 11 students and good with a percentage of $77 \%$ then followed by good category 4 students with a percentage of $23 \%$. To be clearer, the scores that have been achieved by students are described in Figure 2 (pie chart) below.

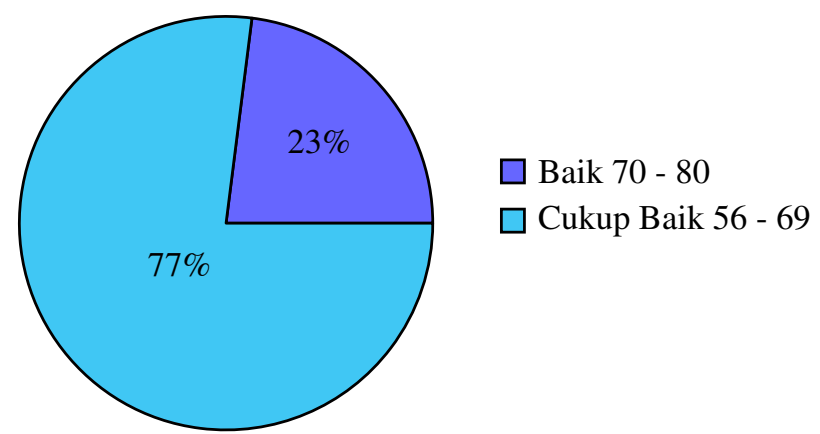

Figure 2. PGSD Student Creativity Results

Based on Figure 2, it can be seen that the highest percentage, which is $77 \%$, is the number of students who score 56-69 which is categorized as good enough. Meanwhile, 23\% is the number of students who score 70-80 in good category. The test results in the table above are a combination of the "creativity aspect". 


\section{CONCLUSION}

Based on the test results assessed from the research instrument, it was found that students were able to compose songs in sign language hood enough. This is shown in the results where 77\% with a score of 59-69 with a total of 11 students were able to compose songs into sign language with reference data and videos that have been shown. Meanwhile 23\% with a score of 70-80 with a total of 4 students were able to compose songs into sign language well, based on the same reference.

\section{REFERENCES}

Djamarah, S. B., \& Zain, A. (2002). Strategi Belajar Mengajar. Jakarta: Rineka Cipta.

Haryati, L. F., Radiusman, R., Nurmawanti, I., Anar, A. P., \& Widodo, A. (2020). Optimalisasi Penggunaan Media Pada Anak Berkebutuhan Khusus di MI NW Tanak Beak Narmada. PROGRES PENDIDIKAN, 1(2), 88-98.

Layyinah, L. (2017). Menciptakan Pembelajaran Fun Learning Based on Scientific Approach dalam Pembentukan Karakter Peserta Didik pada Pembelajaran PAI. TARBAWY : Indonesian Journal of Islamic Education, 4(1), 1. doi:10.17509/t.v4i1.6987

Nurmawanti, I., Haryati, L. F., Radiusman, R., Anar, A. P., \& Novitasari, S. (2020). Problematika dan Tindakan Guru Dalam Menghadapi Anak Berkebutuhan Khusus di MI NW Tanak Beak. PROGRES PENDIDIKAN, 1(2), 134-142.

Radiusman, R., Nurmawanti, I., Novitasari, S., Haryati, L. F., \& Simanjuntak, M. (2020). Sikap Guru Terhadap Anak yang Berkebutuhan Khusus di SD IT Anak Sholeh Mataram. PROGRES PENDIDIKAN, 1(2), 8087.

Rahmatih, A. N., Wardani, K. S. K., Warthini, N. L. P. N. S., Astria, F. P., \& Fauzi, A. (2020). Profil Siswa Berkebutuhan Khusus di SDN 20 Mataram. PROGRES PENDIDIKAN, 1(2), 128-133.

Sanjaya, W. (2006). Strategi Pembelajaran. Jakarta: Kencana Prenada Media Group.

Sugiyono, S. (2014). Metode Penelitian Pendidikan (Pendekatan Kuantitatif, Kualitataif, dan R \& D). Bandung: Alfa Beta.

Sutisna, D., Indraswati, D., Nursaptini, N., Novitasari, S., \& Sobri, M. (2020). Penerapan Program Pendidikan Inklusi di SDN 1 Sangkawana Lombok Tengah. PROGRES PENDIDIKAN, 1(2), 115-127.

Wardani, K. S. K., Warthini, N. L. P. N. S., Rahmatih, A. N., Astria, F. P., \& Nurwahidah, N. (2020). Pelaksanaan Program Pendidikan Inklusif Bagi Anak Berkebutuhan Khusus di SDN 20 Mataram. PROGRES PENDIDIKAN, 1(2), 99-105.

Warthini, N. L. P. N. S., Wardani, K. S. K., Rahmatih, A. N., Nurwahidah, N., \& Astria, F. P. (2020). Pemenuhan Hak Anak Berkebutuhan Khusus dalam Implementasi Program Pendidikan Inklusif di SDN 20 Mataram. PROGRES PENDIDIKAN, 1(2), 106-114.

Widodo, A., Haryati, L. F., Maulyda, M. A., Umar, U., \& Erfan, M. (2020). Proses Identifikasi Peserta Didik Berkebutuhan Khusus Di MI NW Tanak Beak Kabupaten Lombok Barat. PROGRES PENDIDIKAN, $1(2), 63-71$. 